\title{
Left ventricular haemodynamic effects in a patient with endocarditis
}

\author{
M. A. W. Habets · S. Bouwmeester
}

Accepted: 19 July 2021 / Published online: 17 August 2021

(C) The Author(s) 2021

A 53-year-old man, with no medical history, presented to the emergency department with malaise and severe shortness of breath two months after a dog bite. On physical examination, the heart rate was 95 beats per minute, blood pressure was $128 / 48 \mathrm{~mm} \mathrm{Hg}$ and a cardiac decrescendo diastolic murmur as well as a Duroziez sign were noted. Laboratory tests showed elevated infection parameters (C-reactive protein [CRP] $105 \mathrm{mg} / \mathrm{l}$, leucocytes $\left.22.510^{\wedge} 9 / \mathrm{l}\right)$, liver enzymes and N-terminal pro-brain natriuretic peptide (NTpro-BNP: $3532 \mathrm{pg} / \mathrm{ml}$ ). Echocardiography revealed a large vegetation on the aortic valve with severe regurgitation (Fig. 1a). A colour M-mode Doppler imaging of the transmitral flow is shown (Fig. 1b). What is your diagnosis?

\begin{abstract}
Answer
You will find the answer elsewhere in this issue.

Conflict of interest M.A.W. Habets and S. Bouwmeester declare that they have no competing interests.

Open Access This article is licensed under a Creative Commons Attribution 4.0 International License, which permits use, sharing, adaptation, distribution and reproduction in any medium or format, as long as you give appropriate credit to the original author(s) and the source, provide a link to the Creative Commons licence, and indicate if changes were made. The images or other third party material in this article are included in the article's Creative Commons licence, unless indicated otherwise in a credit line to the material. If material is not included in the article's Creative Commons licence and your intended use is not permitted by statutory regulation or exceeds the permitted use, you will need to obtain permission directly from the copyright holder. To view a copy of this licence, visit http://creativecommons.org/licenses/by/4.0/.
\end{abstract}

M. A. W. Habets $(\bowtie) \cdot$ S. Bouwmeester

Department of Cardiology, Catharina Hospital Eindhoven,

Eindhoven, The Netherlands

margot.habets@catharinaziekenhuis.nl 


\section{Advertisement placed here.}

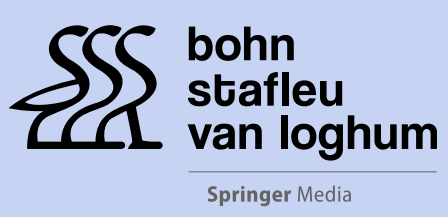

Houten 2021 


\section{Advertisement placed here.}

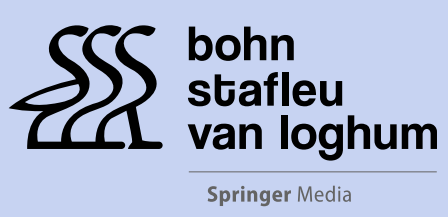

Houten 2021 

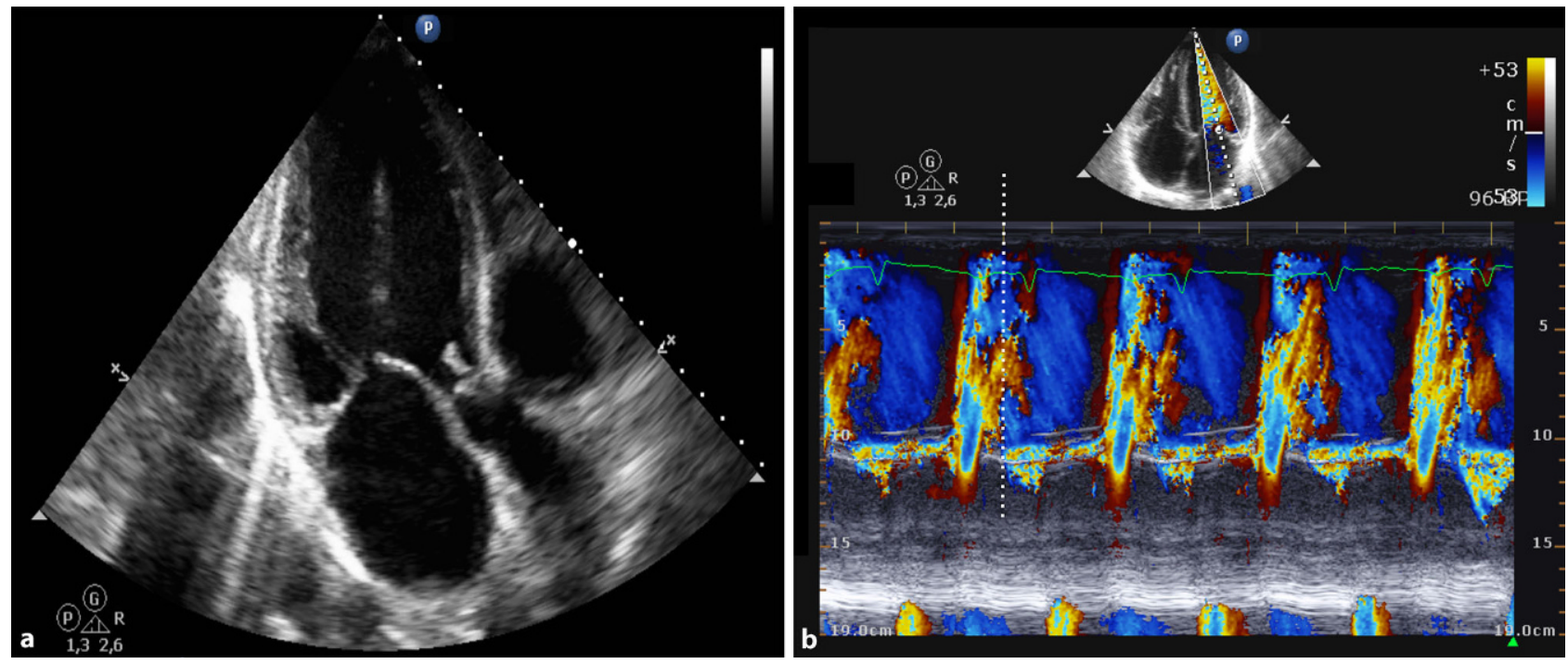

Fig. 1 a Still frame from apical three-chamber view; $\mathbf{b}$ Colour M-mode of transmitral flow from the apical four-chamber view 